\title{
Pembuatan Aplikasi Android Sebagai Media Pembelajaran Menarche Pada Remaja Putri Desa Kemuning Lor Kabupaten Jember
}

\author{
Bakhtiyar Hadi Prakoso ${ }^{1 *}$, Veronika Vestine ${ }^{2}$, Gandu Eko Julianto Suyoso ${ }^{3}$, \\ Dina Fitriyah $^{4}$, Surya Dewi Puspita ${ }^{5}$ \\ 1,2,3,4,5 Jurusan Kesehatan, Politeknik Negeri Jember \\ ${ }^{1}$ bakhtiyar.hp@polije.ac.id, ㄹveronikavestine@polije.ac.id, ${ }^{3}$ gandu.eko.js@ polije.ac.id, \\ ${ }^{4}$ dinafitriyah@polije.ac.id, ${ }^{5}$ surya_puspita@polije.ac.id
}

\begin{abstract}
Puberty is a period of transition from childhood to adolescence. One of the signs experienced by adolescent girls is the presence of menarche. Seeing the current condition of society, many parents, especially mothers, are less than optimal in providing education for their daughters when experiencing the menarche process. In this service activity, an android application will be created that functions to help menarch education. The activity began with the application design process and socialization to young women in the village of Kemuning Lor, Jember Regency. The results of this community service activity are as many as $80 \%$ of participants feel helped by the android application. In the future, the android application that is built can be developed by increasing educational content related to menarche.
\end{abstract}

Keywords : menarche, android, kemuning lor

\begin{abstract}
Abstrak
Masa puber merupakan masa transisi dari anak-anak ke remaja Salah satu tanda yang dialami oleh remaja perempuan adalah adanya menarche. Melihat kondisi masyarakat saat ini banyak orang tua khususnya ibu yang kurang maksimal memberikan edukasi bagi anak perempuannya ketika mengalami proses menarche ini. Dalam kegiatan pengabdian ini akan dibuat aplikasi android yang berfungsi untuk membantu edukasi menarch. Kegiatan dimulai dengan proses rancang bangun aplikasi serta sosialisasi ke remaja putir di desa Kemuning Lor Kabupaten Jember. Adapun hasil dari kegiatan pengabdian kepada masyarakat ini adalah sebanyak $80 \%$ peserta merasa terbantu dengan adanya aplikasi android. Kedepannya aplikasi android yang dibangun dapat dikembangkan dengan memperbanyak konten edukasi terkait dengan menarche.
\end{abstract}

Kata Kunci: menarche, android, kemuning lor

*Penulis Korespondensi : Bakhtiyar Hadi Prakoso

\section{PENDAHULUAN}

Masa puber merupakan masa transisi dari anak-anak ke remaja. Setiap orang pernah mengalaminya. Proses transisi ini ditandai oleh tanda-tanda biologis baik lakilaki maupun perempuan. Salah satu tanda yang dialami oleh remaja perempuan adalah adanya menarche. Menarche ini merupakan sebuah proses alamiah yang dialami oleh remaja putri dengan keluarnya menstruasi di pada periode pertama. Selain berdampak pada pada perubahan biologis, tentunya hal tesebut berdampak ke koondisi psikis (Juwita and Yulita 2018).

Orang tua merupakan pendidik pertama dalam sebuah rumah tangga. Dalam hal ini ibu mempunyai peranan penting dalam proses menarche. Perananan 
tersebut berupa pemberian pendidikan terkait dengan menarche (Anwar and Febrianty 2017). Melihat kondisi masyarakat saat ini banyak orang tua khususnya ibu yang kurang maksimal memberikan edukasi bagi anak perempuannya ketika mengalami proses menarche ini.

Proses pembelajaran saat ini yang dulunya bersifat tatap muka langsung, pada saat ini mulai tergantikan pembelajaran mandiri. Berkembangnya teknologi saat ini telah merevolusi kegiatan pembelajaran yang berbasis digital (Efendi 2019). Berbagai macam media pembelajaran dibuat dengan memanfaatkan teknologi informasi. Aktifitas pembelajaran lebih menarik, karena didukung dengan media pembelajaran lebih variatif diantaranya adalah dengan memanfaatkan smartphone (Ruziana, Imran 2017).

Dari hasil survey yang telah dilakukan oleh Kominfo, saat ini masyarakat telah menggunakan telepon pintar sebagai media pembelajaran. Sebanyak $26 \%$ dari seluruh total pengguna telpon pintar diindonesia telah memanfaatkan media tersebut untuk belajar.(Kementerian Komunikasi dan Informatika Republik Indonesia 2019). Berbagai aplikasi pembelajaran berbasis telpon pintar saat ini telah berkembang pesat Salah satunya adalah yang berbasis android. Android merupakan salah satu Sistem operasi yang terdapat pada ponsel pintar. Saat ini, jumlah pengguna android sebesar 90,85\% dari keseluruahan pengguna telpon pintar(Statecounter 2021)

Dengan berkembangnya jumlah pemakai smartphone yang berbasis android, saat ini banyak aplikasi pembelajaran yang telah dikembangkan khususnya untuk pendidikan Kesehatan remaja. diatarannya yaitu : Aplikasi Edukasi Gizi Remaja Berbasis Android Untuk Pencegahan Stunting(M. E. Putra et al. 2021), Aplikasi Pengembangan Aplikasi Edukasi Kesehatan Reproduksi Remaja (Novaeni et al. 2018), Pengembangan Aplikasi Psikologi Remaja Berbasis Android (M. S. Putra and Wati 2021)

Desa kemuning Lor merupakan salah satu desa yang terdapat di Kabupaten Jember Jawa Timur. Sebagaimana desa yang lain, Desa Kemuning Lor mempunyai Gerakan PKK yang cukup aktif dalam upaya mendukung pembangunan masyarakat. Kegiatan yang dilakukan berfokus dalam pemberdayaan dan kesejahteraan keluarga dimana salah satu pokok gerakannya adalah kesehatan.

Sejalan dengan hal tersebut, pada kegiatan pengabdian masyarakat ini akan dikembangkan sebuah aplikasi android untuk pembelajaran mandiri terkait dengan menarche (Menstruasi pertama). Dimana aplikasi ini nantinya ditujukan untuk masyarakat remaja maupun Ibu-ibu PKK di desa Kemuning Lor kecamatan arjasa kabupaten jember, jawa timur. Aplikasi yang dibuat dengan tambahan fitur Bahasa madura, yang notabennya masyarakat kemuning lor ini mayoritas suku madura, yang didalam keseharianannya berbahasa madura.

\section{METODE}

Adapun metode pelakasanan yang dilakukan didalam kegiatan pengabdian masyarakat ini adalah sebagai berikut

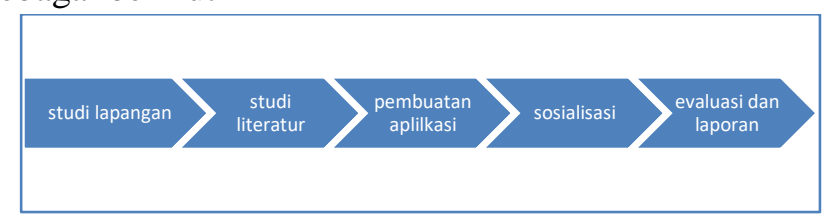

Gambar 1. Metode Pelaksanaan

\section{- $\quad$ Studi lapangan}

Pada tahapan ini dilakuakan survey terhadap kondisi lokasi yang dipergunakan untuk kegiatan pengabdian masyarakat. Hasil dari survey ini diperoleh bahwa objek dari program kegiatan ini merupakan remaja prutri yang bertempat tinggal di desa kemuning lor kec arjasa kab jember.

\section{- Studi literatur}

Pada tahapan ini dilakukan studi terakit dengan materi yang diberikan yaitu tentang menarki. Selain tentang menarki, selain itu pada tahapan ini juga dipelajari tentang pembuatan aplikasi android dimana aplikasi android ini nantinya sebagai sarana untuk pembelajaran

- Pembuatan aplikasi

Proses pembuatan aplikasi dilakukan melalui Analisa kebutuhan terhadap aplikasi android

- Sosialisasi

Pada kegiatan ini dilakukan ssosialisasi menarki terhadap objek pengabdian masyarakat

- Evaluasi dan Pembuatan laporan 
Pada tahapan ini dilakukan evaluasi terhadap kegiatan dan aplikasi yang telah dibuat. Setelah evaluasi selesai Langkah selanjutnya yaitu adalah pembuatan laporan dari kegiatan pengabdian kepada masyarakat

\section{HASIL DAN PEMBAHASAN}

\section{a. Analisa Kebutuhan}

Kegiatan pembuatan aplikasi dimulai dengan proses pengambilan data. Pengambilan data ini digunakan untuk menggali infomasi terkait dengan kebutuhan pengguna. Pengambilan data dilakukan dengan melibatkan perangkat desa, remaja putri dan orangtua, dan pakar dalam hal ini adalah dosen yang ahli dalam bidang kebidanan.

Aplikasi dirancang berbasis mobile. Hal tersebut menjadi pilihan karena, raata-rata remaja putri maupun orang tua saat ini telah memiliki smartphone yang berbasis android. Atas dasar kondisi tersebut aplikasi yang dibangun beberbasiskan di android, yang nantinya pengguna dapat mengakses aplikasi tersebut melalui Google Play

Dalam proses pengambilan data didapatkan kebutuhan yang aplikasi yang mempunyai fitur dua bahasa. Dalam hal ini bahasa yang dipergunakan adalah Bahasa Indonesia dan Bahasa Madura. Selain fitur Bahasa tersebut aplikasi juga dapat digunakan uutuk pembelajaran. Fitur pembelajaran ini teridiri dari artikel dalam bentuk teks maupun dalam bentuk video pembelajaran. Adapun pembelajaran dari bentuk video ini ditujukan agar proses pembelajaran lebih interaktif.

\section{b. Perancangan Aplikasi}

Setelah melalui tahapan analisi kebutuhan dari aplikasi. Proses selanjutnya adalah perancangan aplikasi. Perancangan aplikasi digambarkan dalam bentuk usecase diagaram. Adapun perancagannya dapat dilihat pada gambar berikut ini

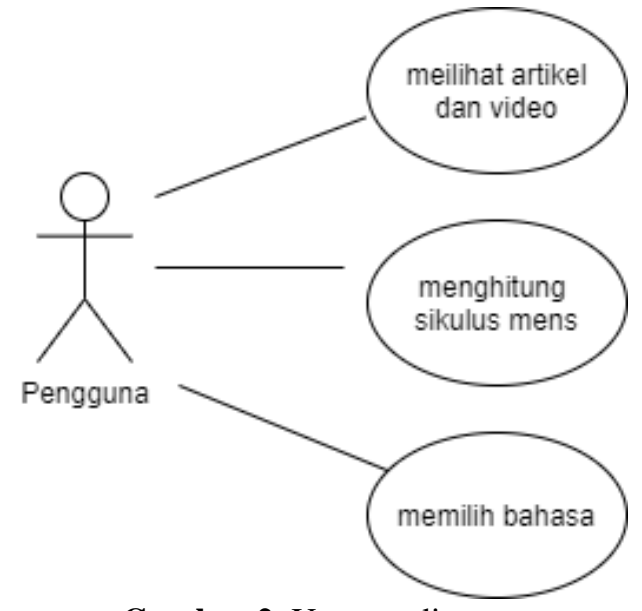

Gambar 2. Usecase diagram

Aplikasi yang dikembangkan terdapat 2 fitur utama yaitu :

- Fitur memilih Bahasa

Fitur ini memungkinkan bagi pengguna untuk memilih Bahasa. Bahasa yang tersedia untuk aplikasi ini adalah Bahasa Madura dan Bahasa Indonesia

- Fitur melihat artikel pembelajaran

Fitur ini digunakan sebagai media pembelajaran bagi pengguna, didalamnya terdapat dua macam. Artikel dalam bentuk teks dan dalam bentuk video. Masingmasing artikel atau video terdapat dua macam Bahasa. Yaitu Bahasa Indonesia dan Bahasa madura

- Fitur melihat siklus calendar haid

Fitur ini dipergunakan untuk melihat siklus haid bagi perempuan. Didalam fitur ini akan ditunjukkan

\section{c. Pembuatan Apilkasi}

Aplikasi dibuat berbasi android. Tools yang dipergukan adalah android studio. Bahasa pemrograman yang dipergunakan adalah kotlin. Dengan versi target SDK 30 dan targer minimal SDK 21.

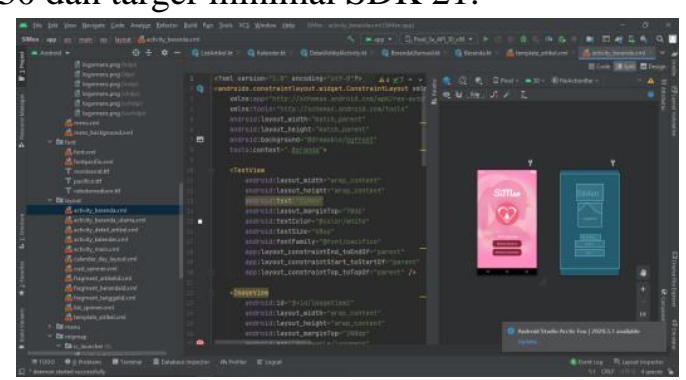

Gambar 3. Proses Pembangunan Aplikasi Dengan Android Studio 
Pemilihan SKD dengan target minimal 21 dilakukan karena pada SDK tersebut hampir seluruhnya kompatibel dengan perangkat seluler android saat ini. Berikut ini adalah tatap muka aplikaisi yang dibuat

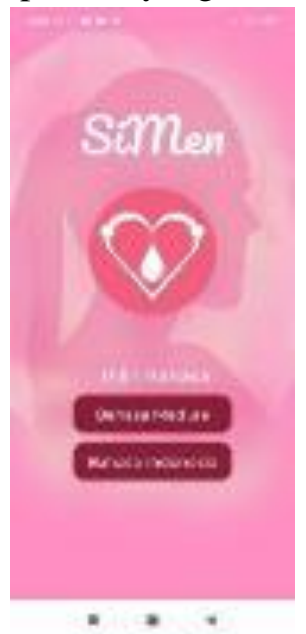

Gambar 4. Halaman Pilihan Bahasa

Gambar diatas merupakah halaman yang dipergunakan untuk memilih Bahasa. Dari tampilan ini pengguna dapat memulih Bahasa Indonesia atau Bahasa Madura untuk masuk kedalam aplikasi

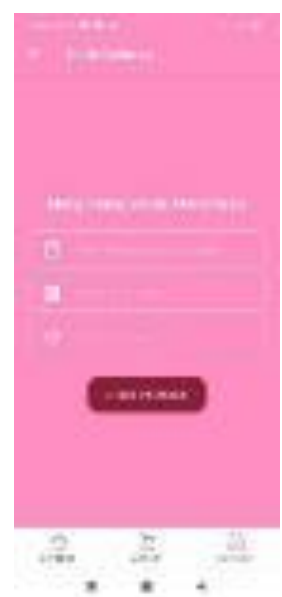

Gambar 5. Halaman Perhitungan

Gambar diatas merupakan tatap muka untuk memasukkan data siklus haid. Masukan terdiri dari tiga jenis yaitu tanggal pertama haid, rata-rata haid, dan yang terakhir periode haid yang merupakan jumlah hari dari pertama menstruasi sampai dengan hari menstruasi berikunya

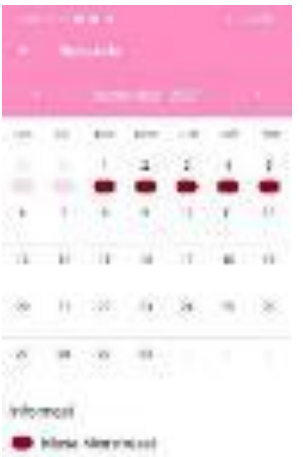

Gambar 7. Hasil Perhitungan Mens

Gambar diatas merupakan tampilan untuk melihat hari haid selanjutnya. Pada tanggal tersebut terdapat tanda merah dibawah tanggal. Tanda ini merupakan prediksi masa haid yang dihitung berdasarkan data yang dimasukan pada gambar sebelumnya.

\section{d. Uji Coba}

Uji coba dilakukan untuk menilai apakah aplikasi yang telah dibuat tidak terjadi kesalahan. Uji coba dilakukan dengan mencoba berbagai fitur yang ada dengan menggunakan blackbox testing. Tabel hasil uji coba dapat dilihat pada table dibawah ini

Tabel 1. Skenario Pengujian

\begin{tabular}{|l|l|l|l|}
\hline $\begin{array}{l}\text { Skenario } \\
\text { pengujian }\end{array}$ & $\begin{array}{c}\text { Kasus } \\
\text { Pengujian }\end{array}$ & $\begin{array}{c}\text { Hasil yang } \\
\text { diaharapkan }\end{array}$ & $\begin{array}{c}\text { Hasil } \\
\text { pengujian }\end{array}$ \\
\hline $\begin{array}{l}\text { Menekan } \\
\text { tombol } \\
\text { Bahasa } \\
\text { madura }\end{array}$ & $\begin{array}{l}\text { Ketuk } \\
\text { tombol } \\
\text { Bahasa } \\
\text { madura }\end{array}$ & $\begin{array}{l}\text { Tampil } \\
\text { halaman } \\
\text { beranda } \\
\text { berbasahasa } \\
\text { madura }\end{array}$ & Sesuai \\
\hline $\begin{array}{l}\text { Menekan } \\
\text { tombol } \\
\text { Bahasa } \\
\text { Indonesia }\end{array}$ & $\begin{array}{l}\text { Ketuk } \\
\text { tombol } \\
\text { Bahasa } \\
\text { indonesia }\end{array}$ & $\begin{array}{l}\text { Tampil } \\
\text { halaman } \\
\text { beranda } \\
\text { dengan Bahasa } \\
\text { Indonesia }\end{array}$ & Sesuai \\
\hline $\begin{array}{l}\text { Menekan } \\
\text { menu } \\
\text { artikel }\end{array}$ & $\begin{array}{l}\text { Ketuk menu } \\
\text { artikel }\end{array}$ & $\begin{array}{l}\text { Tampil } \\
\text { halaman } \\
\text { artikel }\end{array}$ & Sesuai \\
\hline $\begin{array}{l}\text { Menekan } \\
\text { Menu } \\
\text { beranda }\end{array}$ & Ketuk menu & $\begin{array}{l}\text { Tampil } \\
\text { halaman } \\
\text { beranda }\end{array}$ & Sesuai \\
\hline
\end{tabular}




\begin{tabular}{|l|l|l|l|}
\hline $\begin{array}{l}\text { Skenario } \\
\text { pengujian }\end{array}$ & $\begin{array}{l}\text { Kasus } \\
\text { Pengujian }\end{array}$ & $\begin{array}{l}\text { Hasil yang } \\
\text { diaharapkan }\end{array}$ & $\begin{array}{c}\text { Hasil } \\
\text { pengujian }\end{array}$ \\
\hline $\begin{array}{l}\text { Menekan } \\
\text { menu } \\
\text { kalender }\end{array}$ & $\begin{array}{l}\text { Klik menu } \\
\text { kalender }\end{array}$ & $\begin{array}{l}\text { Tampil } \\
\text { harlaman } \\
\text { hitung siklus } \\
\text { haid }\end{array}$ & Sesuai \\
\hline $\begin{array}{l}\text { Menekan } \\
\text { tombol } \\
\text { lihat } \\
\text { periode }\end{array}$ & $\begin{array}{l}\text { Ketuk } \\
\text { tombol lihat } \\
\text { periode }\end{array}$ & $\begin{array}{l}\text { Tampil kaleder } \\
\text { periode haid }\end{array}$ & Sesuai \\
\hline
\end{tabular}

\section{e. Sosialisasi}

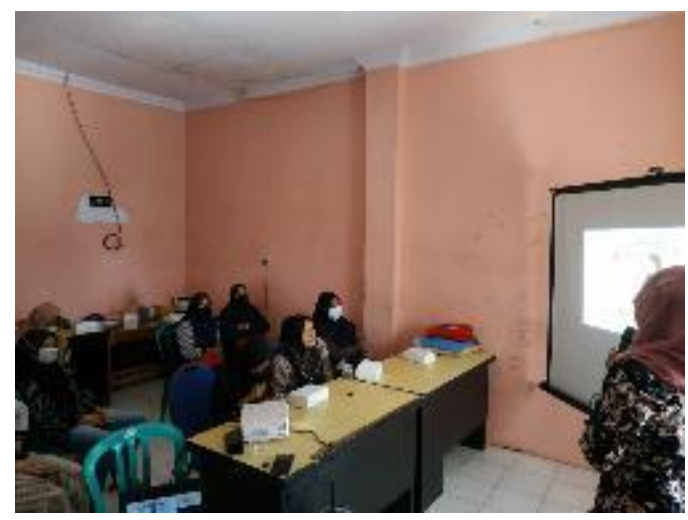

Gambar 8. Proses Sosialisasi

Kegiatan sosialisasi penggunan aplikasi Simen dilakukan dibalai desa Kemuning Lor Kec. Arjasa, Kab Jember. Kegiatan ini diikuti oleh 20 orang yang terdiri dari remaja putri dan orang tua. Didalam kegiatan ini dilakukan sosisalisasi terakait dengan menarche serta penggunaan aplikasi simen. Selain kegiatan sosialisasi teraikat dengan menarche.pada kegiatan ini jiga dilakukan pengisian kuisioner terhadap kepuasan aplikasi. Dari kuisioner tersebut sebanyak $80 \%$ peserta merasa terabantu dengan aplikasi

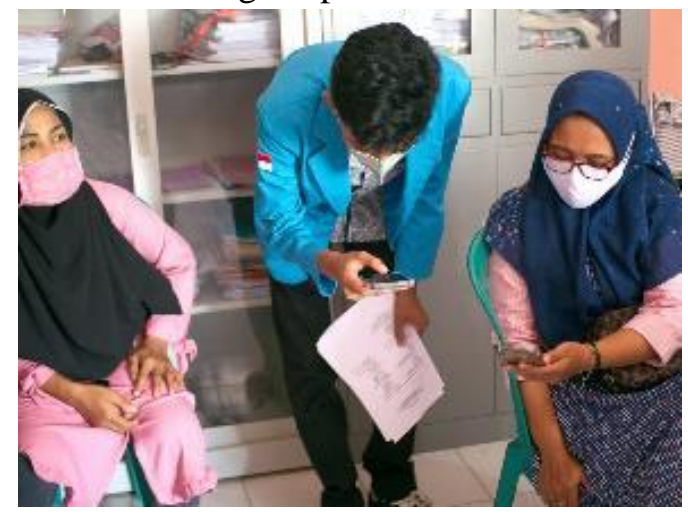

Gambar 9. Proses Pendampinngan Kepada Para Peserta
Gambar diatas merupakan proses pendampingan pemakaian aplikasi yang di bantu oleh mahasiswa Polije

\section{KESIMPULAN}

Adanya Program Pengabdian kepada masyarakat ini memberikan dampak yang positif bagi mitra yaitu PKK Desa Kemuning Lor. Program yang telah dilaksanakan membantu PKK Desa Kemuning Lor dalam mendukung pemberdayaan dan kesejahteraan keluarga dalam bidang kesehatan. Sebanyak $80 \%$ dari jumlah total keseluran peserta edukasi merasa terbantu dengan adanya program ini. Dampak yang dihasilkan dari program kegiatan pengabdian ini adalah bertambahnya pengetahuan ibu-ibu PKK tentang kesehatan reproduksi remaja putri dalam persiapan menghadapi menstruasi pertama (menarche).

Sebagai tindak lanjut tindak lanjut dari pengembangan kegiatan pengabdian kepada masyarakat ini. Aplikasi dapat diperbaharui secara berkala dengan menambah konten baik video maupun artikel. Pengembangan aplikasi dapat juga dilakukan dari segi penambahan fitur dan pembaharuan tampilan dari aplikasi

\section{UCAPAN TERIMA KASIH}

Ucapan terimakasih disampaikan kepada politeknik negeri jember yang telah memberikan kesempatan bagi penulis untuk membuat aplikasi dalam rangka melaksanakan kegiatan program pengabdian kepada masyarakat. Kegiatan pengabdian masyarakat ini merupakan kegiaatan dari pendanaan PNBP Politeknik Negeri Jember.

\section{DAFTAR PUSTAKA}

Anwar, Chairanisa, and Rikha Febrianty. 2017. "Hubungan Pengetahuan, Sikap Dan Peran Ibu Dengan Kesiapan Remaja Putri Menghadapi Menarche Pada Siswi Kelas 4-6 Di SD 3 Peuniti Kota Banda Aceh.” Journal of Healthcare Technology and Medicine 3(2): 154.

Efendi, Neng Marlina. 2019. "Revolusi Pembelajaran Berbasis Digital (Penggunaan Animasi Digital Pada Start Up Sebagai Metode Pembelajaran Siswa Belajar Aktif)." Habitus: Jurnal Pendidikan, Sosiologi, \& Antropologi 2(2): 173 . 
Juwita, Sellia, and Nova Yulita. 2018. "Hubungan Pengetahuan Dengan Kesiapan Remaja Putri Dalam Mengahadapi Menarche.” JOMIS (Journal Of Midwifery Science) 2(2): $50-54$.

http://jurnal.univrab.ac.id/index.php/jomis/article/view/ 411.

Kementerian Komunikasi dan Informatika Republik Indonesia. 2019. "Survey Pengguna TIK Serta Implikasinya Terhadao Aspek Sosial, Budaya Dan Ekonomi Masyarakat."

Novaeni, Nisa, Dharminto Dharminto, Farid Agusyahbana, and Atik Mawarni. 2018. "Pengembangan Aplikasi Edukasi Kesehatan Reproduksi Remaja Berbasis Android Untuk Pembelajaran Biologi Di Sma Pius Kabupaten Purworejo Tahun 2017.” Jurnal Kesehatan Masyarakat (e-Journal) 6(1): 138-47.

Putra, Meiki Eru et al. 2021. "Efektifitas Aplikasi Edukasi Gizi Remaja Berbasis Android Untuk Pencegahan Stunting." 6(2): 443-51.

Putra, Mujono Sang, and Yeni Rahma Wati. 2021. "Pengembangan Aplikasi Psikologi Remaja Berbasis Android (API MADRID) Sebagai Solusi Dalam Mengatasi Permasalahan Pada Usia Remaja (Studi Pada SMA N 2 Dompu)." Jurnal Pendidikan 9(1): 86-98.

Ruziana, Imran, Izhar Salim. 2017. “Analisis Penggunaan Smartphone Sebagai Media Pembelajaran Terhadap Hasil Belajar Siswa Sman 1 Teluk Keramat." Jurnal Pendidikan dan Pembelajaran Khatulistiwa 7(7): 1-8.

Statecounter. 2021. "Mobile Operating System Market Share Indonesia Android." https://gs.statcounter.com/osmarket-share/mobile/indonesiaandroid. 